\title{
Gender, Generation and Identities in Vancouver's African Diaspora
}

\author{
Gillian Creese \\ University of British Columbia, Vancouver, BC, Canada \\ creese@mail.ubc.ca
}

\begin{abstract}
This paper explores multi-generational shifts in identities and community building among the 'new' African diaspora in Vancouver, Canada. Drawing on interviews with adult migrants from sub-Saharan Africa, teen migrants, and second-generation adults, the paper highlights how diasporic identities are gendered, racialized, and place-based. The first generation struggles to remain African, with men focused more on maintaining links with the homeland and women engaged more with strategies of homemaking in Canada. In contrast, second-generation young men develop stronger affinities with the nearby African-American diaspora, while their sisters are more likely to identify with the local African-Canadian community and, like their parents, to dis-identify with the larger African-American diaspora.
\end{abstract}

\section{Keywords}

migration; racialization; gender; second generation; masculinity; femininity

\section{Résumé}

Cet article examine les évolutions identitaires multigénérationnelles et les stratégies de renforcement communautaire au sein de la nouvelle diaspora africaine de Vancouver au Canada. Sur base d'entretiens réalisés auprès d'immigrés subsahariens adultes et adolescents ainsi que d'adultes de la deuxième génération, l'article met en lumière les manières dont les identités diasporiques se structurent autour du genre, de la race et de la situation géographique. Si la première génération s'efforce de rester africaine - les hommes se concentrant sur le maintien de liens avec le pays d'origine tandis que les femmes développent des stratégies pour créer un foyer dans la société canadienne, les jeunes hommes de la deuxième génération tenteraient au contraire de renforcer leurs liens avec la diaspora afro-américaine des environs tandis que leurs homologues féminines

\footnotetext{
* The author thanks all the research participants who agreed to be interviewed; her research collaborators at Umoja, Edith Kambere and Mambo Masinda; to research assistants Veronica Fynn, Sanzida Habib, Jeannie Morgan, E. J. Shu, and Brandy Wiebe; the Social Sciences and Humanities Research Council of Canada and Metropolis B.C. for funding these projects; and the anonymous reviewers for their helpful suggestions.
} 
auraient plutôt tendance à s'identifier avec la communauté afro-canadienne locale, et à l'instar de leurs parents, à se désidentifier de l'importante diaspora afro-américaine.

Mots-clés

migration; racialisation; genre; deuxième génération; masculinité; fémininité

\section{Introduction}

It is useful to think of diasporas as fluid, performative, and relational rather than as fixed entities emanating from transnational movements across space. Diasporic experiences produce distinct forms of community, identity, and modes of cultural production marked by hybridity (Vertovec 1997; see also Brah 1996; Gilroy 1987, 1993; Hall 1990). Identities are forged through material and discursive practices of living across transnational spaces that simultaneously constitute political projects located in specific historical times and spaces (Hall 1990, 2000). As Clifford (1994) contends, "the term diaspora is a signifier... of political struggles to define the local, as distinctive community, in historical contexts of displacement" (308). In a similar way Brubaker (2005) argues that diaspora should be perceived as a 'category of practice': “'diaspora' is used to make claims, to articulate projects, to formulate expectations, to mobilize energies, to appeal to loyalties" (12).

As Brah (1996) notes, "the concept of diaspora places the discourses of 'home' and 'dispersion' in creative tension" (192-3). Diasporas form in the context of relations with states ('homeland' and present 'home') and other multiple positioned groups coexisting in the same spaces. These other groups may include earlier diasporic waves from the same homeland (Lewis 1995) and, in the case of former 'settler colonies' like Canada, also in relation to indigenous populations. Some scholars have attempted to differentiate between immigrants who choose to migrate and diasporic communities who do not choose displacement. For example, Clifford (1994) distinguishes between diasporic populations and immigrants "who may experience loss and nostalgia, but only en route to a whole new home in a new place" (307). This distinction is based on an assimilationist reading of the history of European migration in North America, a complex process in which various groups 'whitened' over time (Jacobson 1998). However it does point to the centrality of processes of racialization in contexts of migration for constructing and maintaining diasporic 'difference' across generations. 
This paper focuses on the creation of 'new' African diasporas as part of contemporary waves of migration from Africa to Canada. ${ }^{1}$ There are many African diasporas, emanating from multiple historic dispersions within and outside Africa, as well as diverse contemporary movements. Racialization and marginalization remain central to these experiences. As Zeleza (2005) notes, African diasporas are also commonly described as 'Black diasporas,' for example in the work of Paul Gilroy $(1987,1993)$, yet "rarely are diasporas from other regions draped in colour" (40). Given the size, geographic dispersion, and centuries of such movements, contemporary African diasporas often have to negotiate the presence of earlier African diasporas. This may be especially so for those who migrate to the United States, where the master narrative of slavery and its legacies shapes new African diasporas in complex ways (Kusow 2006). It is less often recognized how the dominance of American popular culture in Canada means African migrants there also grapple with the cultural presence of the African American diaspora. In addition, practices of constructing new diasporic communities and identities are inherently gendered (Brah 1996; Goldring 2001; Kleist 2010; Manuh 2003; Matsuoka and Sorenson 2001; Pasura 2008), as members refashion acceptable modes of masculinity and femininity, and invariably fluid, as the next generation mediates new forms of hybridity (Hall 2000).

Although migrants from sub-Saharan Africa have diverse language, ethnic, religious, national, and colonial histories, in some specific contexts pan-African diasporas are emerging across multiple divisions and identities (Creese 2011; Fumanti and Werbner 2010; Gregoire 2010; Werbner 2010). These new African diasporas reference imagined notions of Africa as a continental homeland, in the context of similar experiences of un-belonging in new spaces of settlement. This article addresses how members of a new African diaspora in one locale, Vancouver, Canada, are constructing community through reference to common African heritage and dis-identification with the African-American diaspora across the border, and how these processes are gendered. ${ }^{2}$ We place particular emphasis on how generational shifts produce divergent identities among the second generation, including greater affinity for African-American popular culture among sons. The following discussion draws on three distinct

\footnotetext{
1) I follow Koser's (2003) terminology of defining the 'new' African diaspora - migrant communities from post-colonial 'Black African' countries who are currently living outside of the African continent - to distinguish recently formed communities from descendants of earlier waves dispersed through slavery.

2) For a more detailed analysis of first-generation experiences, see Creese 2011.
} 
but overlapping research projects conducted in Vancouver: interviews with adult migrants from countries in sub-Saharan Africa; ${ }^{3}$ focus groups with African youth who migrated as teenagers; ${ }^{4}$ and interviews with second-generation adults who grew up in Vancouver. ${ }^{5}$

\section{Situating the New African Diaspora in Vancouver}

Vancouver, with a population of 2.3 million, is a city built on unceded Aboriginal territory and populated by fairly recent immigrants. ${ }^{6}$ In 2006, 40\% of metro Vancouver's population was born outside of Canada, and when we add the children of immigrants, a majority of local households have recent immigrant backgrounds. The diversity of immigrant origins is also noteworthy: for the first time, there are now more immigrants born in Asia than in Europe. One-third of the total population cites British ethnic origins, and another third cite Asian origins, including nearly one in five residents who are Chinese heritage. Fortytwo percent of the population identify as people of color or visible minorities (Statistics Canada 2007: 32, 2008: 32 ). Yet in this diverse metropolis, migrants from sub-Saharan Africa enter a landscape in which they constitute a very small and hyper-visible minority.

Although there has been a Black presence in Vancouver since the city's colonial origins, it has historically been very small, a result of immigration restrictions until the 1970s, and what Puplampu and Tettey (2005) refer to

3) In 2004 interviews were conducted with 61 adults ( 31 women and 30 men) living in metro Vancouver who migrated from 21 countries in sub-Saharan Africa (Burundi, Cape Verde Island, Congo-Brazzaville, DR Congo, Ethiopia, Ghana, Guinea-Conakry, Kenya, Malawi, Mozambique, Nigeria, Rwanda, Senegal, Sierra Leone, South Africa, Sudan, Swaziland, Togo, Uganda, Zambia, and Zimbabwe). Ninety percent were Canadian citizens or permanent residents.

4) In 2009 focus groups were conducted with metro Vancouver high school students who migrated from sub-Saharan Africa as teenagers. The 21 youths (13 girls and 8 boys) came from 11 countries (Burundi, DR Congo, Eretria, Ethiopia, Liberia, Mauritius, Nigeria, Rwanda, Sierra Leon, Somalia, and Sudan). Interviews were also conducted with principals, teachers, settlement workers, and youth workers.

5) Thirty-five interviews were conducted in 2011 and 2012 with adult children of African immigrants (19 women and 16 men) who grew up in metro Vancouver. Their parents came from 13 countries in sub-Saharan Africa (including DR Congo, Ethiopia, Ghana, Kenya, Liberia, Nigeria, Sierra Leone, Somalia, South Africa, Sudan, Togo, and Uganda). Almost a third (29\%) were Canadian born, and the rest migrated as children.

6) The land has never been surrendered through a treaty or an act of law. In 2006 only $2 \%$ of the population of metro Vancouver reported Aboriginal ancestry (Metro Vancouver 2008). 
as 'neo racist practices' that continue to limit migration from Africa. About $10 \%$ of immigrants to Canada currently come from countries in Africa. Most African immigrants settle in the larger cities of Toronto and Montreal, which both have large and overlapping African diasporas with contemporary roots in Africa, the Caribbean, the United States, and many with long lineages in Canada. In contrast, just over $1 \%(1.3 \%)$ of the metro Vancouver population identified as African-born in the 2006 Census. More than a quarter (28\%) of the African-born came from South Africa (including an untold number racialized as White), $11 \%$ from Ethiopia, 9\% from Somalia, $8 \%$ from Ghana, and the rest identified as 'other African' (Statistics Canada Community Profiles 2006 Census). Two-thirds of those who arrived in the decade prior to 2006 were from southern (34\%) and east Africa (33\%) (Masinda and Kambere 2008: 30). Less than $1 \%$ of the population (or just over 20,000 people) identified as Black in the 2006 Census in response to the question about visible minority status (Statistics Canada Special Interest Profiles 2006 Census). In this context of small numbers, diverse origins within sub-Saharan Africa, recent (post-198os) migration, and common experiences of economic and social marginalization in metro Vancouver, a pan-African diaspora identifying itself as an 'African community' has recently developed.

This new African diaspora navigates the social geography of the city and practices of (un)belonging in the context of Canadian nation-building discourses that continue to center Whiteness, and the presence of the AfricanAmerican diaspora just across the border. The African-American diaspora does not overlap in spatial or geopolitical terms, but nevertheless shapes local popular cultural racialization processes, and the social imaginary. 'Becoming Black' is a central element of migration from Africa to Canada. For example, Ibrahim (1999) describes his migration from Sudan to Canada as a 'retranslation' of self:

As a continental African, I was not considered Black in Africa; other terms served to patch together my identity, such as tall, Sudanese, and basketball player. However, as a refugee in North America, my perception of self was altered in direct response to the social processes of racism and the historical representation of Blackness whereby the antecedent signifiers became secondary to my Blackness, and I retranslated myself: I became Black (italics in original; 354).

This process of racialization is mediated through a long history of racist discourses, practices and representations in the U.S. and Canada (Kusow 2006), and contemporary popular cultures of resistance, such as hip-hop, that have emerged among young African Americans (Collins 2005; Jeffries 2011; Rose 2008). 
Both mainstream discourses about, and cultural resistance emanating from, African American youth, are highly gendered. In addition, they have different resonance for African immigrants and for their Canadian-raised children.

\section{Migration and New Identities}

Most migrants from sub-Saharan Africa experience downward economic and social mobility in Canada. The general deskilling of immigrants, and its gendered and racialized dimensions, has been well documented (Frenette and Morrissette 2005; Galabuzi 2006; Picot and Sweetman 2005). A recent study of sub-Saharan African immigrants in metro Vancouver ${ }^{7}$ shows that, even among those who speak fluent English, are highly educated, and left professional and managerial jobs in their home countries, ${ }^{8}$ most are employed in precarious low-wage employment in Vancouver. These employment patterns are gendered: men are more highly educated than women on arrival, and yet a majority of men end up in low-skilled manual labor or unemployment. ${ }^{9}$ Women find it harder to get work because feminized clerical and service jobs (unlike masculinized manual labor) require Canadian experience and privileged local accents, so the majority of women in the study pursue additional post-secondary education in Canada in an effort to improve their job prospects. Yet most women still end up in low-skilled manual or white-collar jobs, or unemployment, in spite of their Canadian educational credentials. ${ }^{10}$ Downward economic mobility produces high levels of poverty, a stark contrast to the relative affluence most left behind in their African homelands (see also Creese and Wiebe 2012).

African migrants are routinely reinscribed as 'others' in everyday interactions. Two common practices that produce 'difference' are pervasive questions about origins, and negative reactions to African English accents. African

7) This data on African immigrants in metro Vancouver comes from my recent book (Creese 2011).

8) Fifty-three percent of men were in professional and managerial jobs, and $7 \%$ were in semiprofessional occupations in Africa. Thirty-two percent of women were in professional and managerial jobs, plus 19\% were in semi-professional occupations in Africa.

9) Eighty percent of men had a post-secondary degree. But $55 \%$ percent were in manual labor in Vancouver, another $14 \%$ were in low-skilled white-collar jobs, and $10 \%$ were unemployed. Only $10 \%$ of men were in professional or managerial occupations.

10) Seventy-four percent of women had a post-secondary degree. Yet $23 \%$ of women were in lowskilled white-collar jobs in Vancouver, $16 \%$ were employed in manual labor, and $16 \%$ were unemployed. Only $10 \%$ of women were in professional or managerial occupations. 
migrants in Vancouver are frequently interrogated about their origins. This simple question - 'where are you from?' - reinforces that Black bodies must be from somewhere else because they cannot be from here. Even those who have lived in metro Vancouver for many years are unable to claim local origins. Laziati, a woman originally from Swaziland with a Canadian graduate degree, explains that in spite of living in the local municipality of Surrey for over a decade, she cannot claim to be from Surrey:

Laziati; '11 'I am from Surrey.' They say, 'No, I mean where are you from? 'And I say, 'Well, I am from Surrey.' But they say, 'No, you are not from Surrey. I mean originally where are you from?' That's what they usually ask you. Yet when other people, other people they ask them, 'Where are you from?' and someone says, 'I am from Surrey,' when they are White, yeah, then you are from Surrey (Interview 6, 2004).

Local reactions to African English accents constitute another kind of 'othering.' Even fluent English speakers educated in Commonwealth countries in English are subject to accent policing (Creese 2010, 2011). African English accents elicit both incomprehension and public reproach. As Bizima, originally from Zambia, observes: "since we can't talk like them, it's really hard to convince them that you can talk sense when they find out what accent you have" (Interview 5, 2004). This routine failure to hear, understand, or value African English speech is exacerbated, especially for women, by frequent public corrections of pronunciation. As Pierre Bourdieu (1977) reminds us, accents are indexes of authority and as such either facilitate or inhibit the ability to be heard. Local accents are routinely privileged in Vancouver, a practice that is singled out as a barrier in the labor market. Many African immigrants, like Kalumbi, a man who came from Uganda more than a decade before, argues that preference for local accents is "a way of hiding racism in accent" (Interview 32,2004 ).

As Ibrahim (1999) reminds us, African migrants arrive in Canada "already constructed, imagined and positioned" through discourses about Blackness (353).U.S. domination of local media and popular culture in Canada compounds the country's own history of White privilege to circulate pejorative discourses about Black people, and particularly about Black masculinity (Abdel-Shehid 2005; Collins 2005; Ibrahim 1999). The combination of economic and social marginalization, downward class mobility, and racialization in turn creates ambivalent subjectivities of 'Canadianness' long after citizenship has been attained. As Bangila, formerly of the Democratic Republic of Congo, observes,

11) Pseudonyms are used to refer to research participants. 
traveling on a Canadian passport provides certain advantages, but similar benefits do not materialize when he is 'at home' in Canada.

Bangila: Traveling with a Canadian passport. That is the only time you feel good about being a Canadian. But once you are in Canada, there is nothing good about being a Canadian. I am truly a Black person (Interview 41, 2004).

Subjectivities of 'Blackness' and 'Africanness' are newly formed in the local context, layered through pre-existing ethnic and national identities forged in Africa, and invoked situationally. Most identify themselves by nationality or ethnic community when speaking with each other, but adopt continental subjectivities when speaking with everyone else. 'Learning to be Black' is central to the emergence of this pan-African identity. As Kivete and Sangara point out, for example, for them, race often trumps national origins (Sierra Leon and Nigeria respectively) for reshaping their lives in Canada:

Kivete: I think they take us as Africans. We are all - the White man sees us as Africans. We are all the same; we are just Africans. You are a Black man, you are a Black man (Interview 50, 2004).

Sangara: You see an African lady. You don't see a Nigerian. That's when you see me; you see an African (Interview 9, 2004).

The similarity of challenges faced in metro Vancouver, and discourses of common African values, help to mediate significant differences of national origins, ethnicity, language, and religion. ${ }^{12}$ Values commonly defined as African include the importance of extended families and communal relationships, lifelong deference to elders, particularly fathers, and hierarchical gender relations (Arthur 2000; Matsuoka and Sorenson 2001). The emerging identity as a local 'African community' that is Black, African and immigrant, ${ }^{13}$ is delineated counter to discourses of 'Canadianness' (animated by liberal individualism and privileging Whiteness) and through dis-identification from the African-American diaspora that pervades youth culture (through African American hip-hop) and mainstream American popular culture (rife with pejorative discourses about

12) Divisions rooted in the African continent have not entirely disappeared. Both adult migrants and the second-generation criticize the internal tensions and politics that sometimes prevent more effective organizing in the local diaspora.

13) The notion of a local African community, therefore, does not include migrants from subSaharan Africa who are not Black (including the large contingent of local White South Africans), nor African-Canadians who are Black but have never lived in Africa. The self-defined 'African community' refers to people racialized as Black who are recent immigrants from Africa, and their children. 
Blackness). Parents try to instill their own cultural values in their youngsters by differentiating themselves from these influences. Their children, on the other hand, are drawn to Canadian liberal values, and many sons, in particular, come to embrace African American youth culture, which enjoys great popularity among adolescent peers, and forms one way of negotiating belonging in Canadian society.

\section{Homemaking and Homelands}

Gender relations are often profoundly unsettled by migration (Donato et al. 2006; Kleist 2010; Morawska 2011; Pasura 2008; Pessar 2003). Not surprisingly, women and men construct the new African community in Vancouver through diverse practices. Gendered community building practices are linked to culturally embedded norms about femininity and masculinity, and to different orientations toward Africa and the 'homeland' and Canada and 'homemaking.' The homeland is "a mythic place of desire in the diasporic imagination," while home is "the lived experience of the locality" (Brah 1996: 192). Activities associated with the homeland receive more public recognition within the diaspora (Goldring 2001), while those associated more with homemaking in Canada merit less acknowledgement.

Women and men in Vancouver's African diaspora both work in the labor market to support their families, but, as is still the case in most Canadian households, women also bear primary responsibility for domestic labor. Perhaps not surprisingly then, much of women's community organizing focuses on providing support to negotiate homemaking and overcome the daily challenges of migration. Support occurs through informal networks of friends and neighbors as well as through organized women's groups. Many African women's groups organize along national lines, though some are also pan-African in composition (Creese 2011: 212-14). Women give each other advice about negotiating local institutions, especially children's schools, health care, social services, jobs and housing, as well as financial and emotional sustenance for new mothers and for bereaved families. As Silata, originally from Zimbabwe, notes, African women in her neighborhood support each other regardless of national origins:

Silata: And even a Sudan family, they had a baby too. We bought them clothes, you know; we congratulate and we are happy for them and share their joy for having children. So, I've been really given support by Africans and we've also returned that too (Interview 22, 2004). 
Women also form the backbone of a growing number of African settlement workers employed in non-profit agencies and local schools to provide a wide range of government funded programs to newcomers. ${ }^{14}$ These forms of community building simultaneously make claims to belong in local spaces, giving substance to the idea of a local 'African community.' Yet women's activities are often overshadowed by political and development organizations that are dominated by men.

There are more than a dozen nationally focused organizations led by men in the community. ${ }^{15}$ These national bodies typically have mandates of "upholding and preserving their culture" (Masinda and Kambere 2008: 43) and, although most hold periodic social functions in which women and children participate, they are oriented more toward developments in the homeland than to settlement issues in Canada. ${ }^{16}$ In addition to these national organizations, there are half a dozen local non-profit organizations concerned with development initiatives in various African countries, most with a focus on education, health, and water (Creese 2011: 218). These organizations are closely connected to maintaining men's ties and status within homeland communities. For example, some initiatives include building and running schools and medical clinics in home villages, on land donated by leaders of the non-profit organization involved, or fundraising for new wells and other improvements in their home villages. Hence much of men's community organizing takes place in the public realm of community politics and development work in homeland communities, and remains primarily focused on Africa.

These gender differences in diasporic practices are linked to different ways that gender relations and identities are destabilized through migration. As other studies have demonstrated, for many men, migration produces a crisis of masculinity (Kleist 2010; Manuh 2003; Pasura 2008). In Vancouver's African diaspora most men experience downward class mobility, difficulty providing

14) In 2004 there were seven front-line settlement workers of African heritage in metro Vancouver; by 2010 this had grown to more than 30 . Like settlement workers from other origins, the vast majority are women with immigrant backgrounds (Creese 2011: 227).

15) Six of these, linked to Nigeria, Burundi, Uganda, Congo-Brazzaville, Ghana, and the Democratic Republic of Congo, are large enough to be incorporated non-profit bodies (Masinda and Kambere 2008: 42-43).

16) In 2009 leaders of several national African organizations came together to create the United African Communities of B.C. to represent the needs of the broader community (Creese 2011: 224). It is also noteworthy that two African-focused settlement organizations have emerged - the Centre for Integration of African Immigrants and Umoja Operation Compassion Society/African Family Services - both headed by men. 
for their families, diminished social status as Black men in local racialized hierarchies, and loss of authority over wives and children in the context of a legal system grounded in individual rights. Involvement in local politics and development work in Africa enhances men's social standing within their homeland communities and positions them publicly as leaders within the local African community. Similar to studies of Mexican men in the US (Goldring 2001), Somali men in Denmark (Kleist 2010), and Ghanaian men in Toronto (Manuh 2003), men's focus on ties with their African homelands, spaces where they retain their authority and social status, reaffirms positive masculine identities that are otherwise significantly challenged in Vancouver.

Women experience these changes differently. Downward class mobility and poverty combine with reduced access to childcare and domestic help, difficulty supervising children due to multiple jobs and long hours, damaging racialization processes, and influences of popular culture that pose unfamiliar dangers for their children, all of which heighten women's focus on homemaking and community building within Canada. As domestic workloads intensify alongside long hours in the labor market, women draw on local discourses of women's rights in an effort to renegotiate more equitable domestic relationships with their husbands. The home is, after all, a site of nurturing and oppression for women. In many contexts migration affords legal, economic, and social opportunities for women to more effectively resist male and extended family control, whether through forging more equitable gender relations with spouses, or divorcing husbands who are unwilling to adjust (Arthur 2000; Manuh 2003; Matsuoka and Sorenson 2001; Mianda 2004; Morawska 2011; Pasura 2008). If African men in Vancouver harken back to an earlier time of unquestioned authority and privilege, then, women are more likely to look forward to enhanced power within their families.

Both women and men lament their weakened authority over children in Canada, but gendered norms affect local parenting practices. Over time, most women in the African diaspora come to adapt mothering to the local context, searching for ways to raise their children to fit into their new environment. As Silata, who came from Zimbabwe, comments:

Silata: I want to know how I am going to raise him in this Canadian life. I don't want to change my culture, but at the same time there are things here in Canada that I have to fit in with along with raising my son (Interview 22, 2004).

Women can continue to focus on caregiving while adopting less hierarchical and more permissive parenting styles common in Canada without threatening their identities as good mothers. The same cannot be said for men. Their 
identities as good fathers are firmly tied to the exercise of authority that is profoundly challenged in Canada. Not surprisingly, many men, already contending with diminished status within the economy and civil society, seek to reaffirm their positions of authority within their families (Matsuoka and Sorenson 2001; Kleist 2010; Pasura 2008). For example Furaha, originally from Sudan, complained about the emphasis on children's rights that he believes interferes with his ability to discipline his children:

Furaha: The Canadians and the teachers, they are trying to teach our children the way they want. But it is not like that. It really affects our African culture because you can see when the children come home. They come with some paper, some notes, they say, $911^{17} \ldots$ They will tell you if you are going to do this to me, you are telling me this, I will call that number... I don't like it and can give me a final decision to leave the country for that way because I don't like it (Interview 44, 2004).

Tensions around asserting male authority often lead to more intense conflict between spouses and between fathers and offspring, particularly sons, who clash over how to embody proper African masculinity. As they age, sons also bear the brunt of public surveillance and harassment that accompanies being young, Black, and male in Canada, increasing the appeal of African-American cultures of resistance, and widening the cultural wedge between the second generation and their fathers.

\section{Between Africa and Canada: the Second Generation}

As several studies have shown, the second generation tends to develop hybrid identities as they navigate across, between, and through multiple cultural expectations of parents and mainstream institutions (Handa 2003; Plaza 2006; Pratt 2004). African immigrant youths in North America also negotiate racialized Black identities, a complicated process that sometimes produces affinities with African-American identities (Forman 2001; Ibrahim 1999, 2003; Kelly 1998, 2004), 'dual identities' (Clark 2008, 2009; Okeke-Ihejirika and Spitzer 2005), or explicit distancing from African Americans (Chacko 2003). Below we consider how the confluence of racialization, gender, popular culture, family, school, and place shape identity formation for those growing up in metro Vancouver's African diaspora.

17) 911 is the local code for emergency services. 
Growing up in Vancouver ${ }^{18}$ has led to hybrid identities that emanate from traversing multiple expectations and assumptions. Canada is a 'homeland' for those raised locally, and for many, experiences of migration are embedded in family narratives more than in personal dislocations. The second generation, though often still with much ambivalence, tend to adopt hyphenated Canadian identities (as African-Canadian or sometimes more specific Ghanaian-Canadian, Somali-Canadian etc.), terms that are very rarely embraced, and often explicitly rejected, by their parents. ${ }^{19}$ They must navigate their place as Canadians and as part of the local African diaspora by negotiating three competing, sometimes incommensurate, influences: 1) the values, beliefs, and practices located within their families and the local African community; 2) mainstream Canadian culture and social institutions; and 3) the legacies and contemporary cultural forms associated with the historic African-American diaspora.

Parenting is unsettled by migration since appropriate parenting strategies often do not translate well across different social and cultural environments. So for example, the shift from extended family forms and community responsibility for children in African countries, to the privatized nuclear family in North America, presents significant strains. Expectations around authority, deference, and respect for elders, particularly for fathers, are considered core African values, but these expectations collide with the more individualistic orientation and permissive child rearing common in Canada. This makes it hard for youths to live up to parents' expectations of what it is to be African. It is common for parents to question the 'Africanness' of their own children and to lament that they have 'lost' their offspring in Canada (Creese 2011; Creese, Kambere and Masinda 2011). For example, Jane, a Canadian-born woman in her mid-2os, recalls that her Ghanaian father calls her "whitewashed," a pejorative term that suggests she isn't as African as she should be (Interview 3 , 2011). Lack of fluency in their parents' ancestral languages, a common problem for small, linguistically diverse communities, exacerbates the gap between immigrant parents and their offspring, and impedes deeper forms of cultural understanding.

Lack of familiarity with African languages also forms a wedge within the second generation. Language fluency is used as a barometer of how 'African' different members of the second generation really are. Joy, a woman in her

18) For the purposes of this paper the term second generation refers to both those born in Africa and raised in Canada (often called the 1.5 generation) and those who are Canadian born.

19) The first generation rarely refer to themselves as African-Canadian or Canadian, regardless of citizenship, reflecting the persistence of marginalization and un-belonging (Creese 2011: 199-206). 
late 20 s who migrated from Kenya to Canada at the age of 11, explains that her inability to speak the language of her childhood affects her claims to a Kenyan identity:

Joy: It bothered me before because people who had come as an adult, they'd come and they'd be like, 'Oh, oh you're from Kenya!' Then they'd talk to me. And I'd say, 'I don't understand. Like, I understand what you're saying, but I can't speak it.' Then they'd be like, 'Oh.' Then they'd use that to be better than me. Yeah. Like, 'Oh, you're half-Kenyan' or something (Interview 2, 2011).

Immersion in Canadian culture, especially through the school system and relationships with non-African peers, also fosters ambivalences about the 'Africanness' of the second generation. At the same time, most also question their 'Canadianness.' The quest to be recognized as Canadian is central to belonging for the second generation, raised to expect equal treatment in their homeland. Emphasis on their Canadianness simultaneously distances them from the immigrant diaspora of their parents. But at the same time, being Black in Vancouver renders tenuous a straightforward claim to Canadian identity. Like their parents, the second generation is frequently questioned about their origins, interrogations that even their locally produced English accents do not deter. Hence 'Canadianness,' like 'Africanness,' is often asserted and doubted in the same breath. For example, Danielle, a university student who was born in metro Vancouver to Kenyan parents remembers: "I sometimes felt a little like I wasn't part of either world, the Canadian or African.” Inability to speak her parents' ancestral language separated her from the local 'African world,' while being "the only Black child at school, in my church" made her stand out when she just "wanted so badly to be like everyone else" (Interview 1, 2011).

Children are socialized through local institutions as much as by parents, other family, and members of the larger community. Yet these same institutional influences, so formative for youngsters, may be alien to, and even resisted by, immigrant parents. Public schools are a central site of interpolation of both official and hidden curricula. The Canadian school system reinforces mainstream Canadian values about individualism, personal freedom, self-expression, and an equality rights discourse, while at the same time reproducing Eurocentrism at the heart of Canadian nation-building (Henry et al. 1995). The values of Western liberal individualism are reinforced through other social institutions, from the media to more coercive sites such as social workers, police, and the legal system. Valorizing individualism clashes with more familycentered African values. Even more controversial among the African diaspora, discourses of children's rights conflict with expectations of stronger parental 
authority and discipline, and provide youngsters with an effective tool to shift power relations within families. ${ }^{20}$ As a youth worker suggested, both parents and offspring recognize that the result of these tensions is that "the school criticizes everything that [African] parents do" (Interview 12, 2009). Such messages about the inadequacy of African ways of doing things can discourage youths from identifying with the local African diaspora. At the same time, the racialized underpinnings of Canadian nation-building are also embedded in school curricula (from history lessons to multiculturalism as spectacle), distinguishing the 'rightful' subjects of Canadian liberalism (descendants of migrants from Britain and France in particular) from racialized others whose histories as Canadians are too often an absent presence in the curriculum.

It is at school that the children of African immigrants form friendships with non-African peers and engage with the powerful influences of North American youth culture (Abdel-Shehid 2005; Forman 2001; Ibrahim 1999, 2003; Kelly 1998, 2004). Indeed, negotiating relations with Canadian peers and navigating the pressures of adolescence in North America may be more formative for identities than anything in the official school curriculum. North American youth culture is saturated with images and messages that stress adolescent autonomy from parents, normalize early (hetero)sexuality, glorify high-risk activities including drug and alcohol consumption, and encourage conspicuous consumption and materialism. These are all values that are antithetical to the idealized visions migrants bring with them of adolescent experiences in Africa ${ }^{21}$ and serve to widen the cultural gap between parents and children.

For all adolescents, learning to 'fit in' and be accepted by peers is critical. Mediating relations with peers is both racialized and gendered. It is racialized in the context of White privilege in Canada, the wide circulation of pejorative representations of Black men and women, and small numbers in Vancouver so children of African descent are usually one of the only Black children in their schools. It is gendered and sexualized in the context of ongoing gender inequalities and compulsory heterosexuality, ${ }^{22}$ as adolescents negotiate

20) The most dramatic example is the instruction to call 911 if children need police assistance. African parents recount how threats to call 911 occur frequently as children try to resist parental authority of all kinds, even instructions to turn off the television and go to bed (Creese 2011: 184$87)$.

21) In fact hip-hop culture has a global reach that also influences youths in African countries with consequences that have been characterized as both harmful for youths and contributing to new local forms of creativity and resistance (Ntarangwi 2009; Perullo 2005).

22) The term compulsory heterosexuality is not meant to imply that African youths are necessarily heterosexual, but that heteronormativity (assumptions that everyone is or should be 
normative forms of masculinity and femininity to fit in. For the children of African immigrants, negotiating forms of acceptable masculinity and femininity means navigating often contradictory models and expectations rooted in the local African diaspora, African-American youth culture, and mainstream Canadian culture. How they navigate these influences shapes identities differently for young men and women.

Adolescent boys negotiate masculinity by earning respect from other boys and learning to 'stand up for themselves.' The imminent threat of aggression looms as a means of putting boys in their place within various male status hierarchies (Connell 1995). As Eddie, a high school senior who migrated from Nigeria, explains:

Eddie: You get picked on a lot. So you have to be strong for your own self. Like, you have to, you know, stand up for your own self... So you have to do like do extra work to get respect (Focus Group 4, 2009).

For young Black men, negotiating masculinity also means negotiating racialized identities in the context of images of Black masculinity that are saturated with pejorative associations of violence and crime. These representations are embedded in North American history, contemporary popular culture, and ongoing processes of marginalization (Collins 2005; Kelly 1998, 2004). Hence young men in the local African diaspora describe learning to walk a fine line between 'defending' themselves and 'earning respect,' and simultaneously learning to be 'humble,' 'mellow,' and 'cautious' so as not to arouse the interest of the authorities. They are ever aware that they are young Black men operating in a field of White privilege. For example, second-generation boys and young men face frequent harassment by the police, border guards, and others in authority, challenges about the right to occupy public spaces, and are frequently perceived as instigators when youthful confrontations do occur, all routine aspects of living with the devalued status of being young Black and male in Canada (Focus Groups 2, 4, 7, and 8, 2009).

Such experiences can heighten affinities with the African-America diaspora that includes embracing representations of powerful images of street-wise Black masculinity as forms of resistance to racism. In addition, the popularity of commercial American hip-hop among youths of all backgrounds forms a filter through which peers perceive African-Canadian youths. Bob, born in Canada to parents from Ethiopia, remembers being treated as 'special' and

heterosexual) and homophobia (fear or hatred of LGBTQ persons) are prevalent, making it more difficult for youths to safely identify as anything but heterosexual. 
'cool' in high school, a 'novelty' because there were so few Black kids in his school. At least this was so as long as he performed Blackness the way his peers expected:

Bob: I think more White kids definitely knew about hip-hop music than I did. I did a lot of smiling and nodding. It was a period of nodding and smiling and not knowing why things were, why people wanted my attention... And then with that benefit there are also traps and limitations. So you can be good at sports, good at dancing, you can be sociable, you can be loud and bombastic, but you can't be smart. You can't be serious. You can't be critical. You know you can be the guy they will dance with or go to a party with but never the guy they invite home for dinner (Interview 28, 2012).

Adopting the masculine swagger or 'cool pose' valorized in hip-hop provides young Black men with a form of respect from their peers, even as it further divides them from their parents' expectations about respectable Black masculinity.

Second-generation girls and young women face different racialized pressures as they navigate heterosexual femininity. Representations of Black femininity in North America, including in hip-hop, coalesce around hypersexuality, on the one hand, and excessive independence and domination (that is, women who don't need men), widely considered unfeminine or undesirable, on the other hand (Collins 2005; Rose 2008). Living up to conventional (White middle class) forms of beauty and heterosexual femininity are key marks of status in hierarchies among girls, and between them and young men, norms that make it nearly impossible for Black women to measure up. Though threats of violence are less often a means of policing relations among women and girls (though endemic in the policing of women by boys and men), exclusion, gossip, and other psychological forms of harassment among peers can be equally damaging (Currie et al. 2009).

African-Canadian adolescent girls, like their brothers, struggle to 'fit in' and 'stand up for themselves' as they negotiate acceptable forms of femininity. Representations of Black femininity in popular culture provide few routes for earning respect, since sexual double standards mean sexuality and too much independence are both ways of denigrating young women. In commercial hiphop, for example, women typically serve as "decorative eye candy" (Emerson 2002: 123), or as "having great sexual desires, which they can only quench by being degraded for male pleasure" (Stephens and Few 2007a: 6o). As Denise, who came to Canada from Uganda at the age of five, explains, like Black boys, girls are expected to emulate hip-hop too: 
Denise: I think people expected it (hip-hop) to be more of an influence on me because I was Black. I should be acting a particular way and if I didn't want to go out and party, or go out and get drunk, people thought I was odd (Denise, Interview 20, 2012).

As Denise went on to explain, representations of Black women in popular culture are typically "mixed, non-pure Black, where they got some White in them somewhere." She notes that these whitened images of Black female beauty (Stephens and Few 2007b) create identity issues for African-Canadian women.

"My mom's best friend, her daughter, I see it in her. She's just having a hard time with selfidentity. She's Black, dark skinned Black, but she has no one to look up to so she's trying to emulate like Beyonce. She doesn't feel beautiful because she doesn't look like Beyonce" (Interview 20, 2012).

Unlike Bob's memory of being 'special' in high school, an experience shared by many of the young men we interviewed, none of the women remembered being treated this way. Girls were more likely to find it hard to measure up to the beauty standards prevalent in hip-hop, and disinterested in emulating sexual personas that were unlikely to increase, and indeed would more likely decrease, their social status among peers. Instead, girls are more likely to turn to academic achievement as a way of earning respect.

A common narrative among girls focuses on the need to stand up to their teachers who underestimate their capabilities. Standing up to their teachers often involves enlisting the support of other allies, particularly parents and sometimes other sympathetic teachers, who help press their case for access to more challenging courses and curriculum (Focus Groups 2, 3, 7 and 8, 2009). In so doing, second-generation daughters tend to pursue models of femininity that are closer to their parents' expectations, and further removed from dominant representations of Black women in African-American youth culture.

Hence young African-Canadians of both genders encounter oppressive racialized scripts about masculinity and femininity linked to the African-American diaspora, as they try to fit in and stand up for themselves in a context where they are one of very few Black teens in Vancouver. These racialized scripts are contrary to gendered norms in mainstream Canadian (White middle class) culture, and, more important, antithetical to notions of respectable masculinity and femininity in the local African diaspora. The scripts of Black femininity in North American youth culture have little appeal to girls in the local African diaspora, failing to provide a means of gaining respect or fitting in with their peers. Young men, on the other hand negotiate masculinity in more solitary ways rooted primarily in power hierarchies and the quest for respect among boys and men. The widespread popularity of hip-hop provides boys who could 
perform the 'cool pose' with a route to popularity. More so than their sisters, young Black men and boys also routinely experience racialized surveillance and harassment by police and other authorities. These experiences, in turn, reinforce similarities between young Black men's lives in Vancouver and in the United States, providing a basis for closer affinities with the African-American diaspora.

Hence the simultaneous negotiation of race, gender, and sexuality in the local context shapes gendered identities among second-generation AfricanCanadians in complex ways. The sons of African immigrants have a stronger resonance with the oppositional stance of African-American youth culture that is fostered by intense marginalization of young Black men in the United States (Collins 2005; Jeffries, 2011; Rose 2008). Particularly during adolescence, they are more likely to perceive themselves as being part of a larger Black (AfricanAmerican) diaspora, and hence further removed from their fathers' notions of respectable African masculinity. In contrast, their sisters, who do not generally experience the same levels of public surveillance and harassment, and who are offered no viable means of being Black and 'cool,' find little appeal in often misogynous African-American youth culture. Hence daughters are more likely to identify with, and maintain stronger links with, the local African community, even during adolescence.

Jane offers a good example of these trends in her own family. She explains that her brothers (also Canadian born and now in their mid to late 20s) are both estranged from her Ghanaian father, with whom she now has a close relationship after a period of adolescent rebellion. Her father is vocal about how he "hates African-American" culture and therefore is "always trying to differentiate himself" as an African. Her brothers, in contrast, reject their father's model of African masculinity as irrelevant to the Canadian context, and embrace a street-wise masculinity as a way of negotiating a space of respect that they otherwise find lacking. Jane acknowledges that as Black men her brothers face more coercive forms of racism, shaping their affinity with African-American identities in ways that her father cannot understand (Interview 3, 2011).

Seeking to explore their African heritage more as they get older, young women typically express a desire to develop stronger links with the local African community and values as they envision raising their own children. As Jane says, noting the irony of her earlier comments about her father being too strict:

Jane: I think I'll parent like my Dad parented. Well, like, not [that] extreme. I mean, fiveyear-olds doing math homework after school. But, yeah, I want, like, I believe in, like, a lot 
of the values. Like I think North American kids, like have lost. They have too much power in families. And I think that, at least the way my Dad does it, like, you have to respect, like. That's how it should be (Interview 3, 2011).

With the return to African cultural expectations to parent the third generation, many women envision drawing together homemaking and the diasporic homeland, seeking to connect their own children to the local African community as well as to extended family in Africa. Although more research remains to be done, the desire for stronger links seems to be less prevalent for men, even though many leave behind adolescent scripts of oppositional masculinity as they pursue higher education, careers, and contemplate families. For many men, the gendered experiences of being young Black and male in Canada may continue to foster affinities with African Americans while mitigating rebuilding stronger connections with the local African community.

\section{Conclusion}

This exploration of multi-generational shifts in identities and community building practices among Vancouver's African diaspora highlights the centrality of gendered, racialized, and place-based constructions of diaspora. Migrants from diverse countries in Africa are constructing pan-African networks, social solidarity, and identities, with men more directed to the homeland in an effort to secure some of their previous social standing as community leaders and respectable men, and women oriented more to community building and homemaking in the local context as they work to negotiate the many challenges their families face in Canada. For both men and women in the first generation, their collective African identities are reinforced by everyday White privilege in Canada that marks them as permanent foreigners in spite of Canadian citizenship, and against the omnipresent and largely pejorative images of the African-American diaspora that resides across the border yet inhabits part of the cultural geography of metro Vancouver.

If the African-American diaspora serves as a point of dis-identification for the first generation, their offspring navigate a more complex social geography. Young men and women are more likely to identify as African-Canadian rather than as Africans. Growing up in Canada, they expect to be treated equally with other Canadians, but cannot escape the realities of racialization and racism embedded in dominant constructions of Black masculinity and femininity in North America. For many young Black men, in particular, peer rewards for adopting the 'cool pose' of hip-hop, and coercive forms of surveillance 
and routine encounters with authorities, generate resonances with the antiauthoritarian rebellion of much African-American youth culture. Those sons who adopt the 'cool pose' of a street-wise masculine performance are further distanced from their fathers' models of African masculinity. African-American youth culture has much less resonance for second-generation daughters, given the prevalence of misogyny and hyper-heterosexuality, even though, as young women raised in Canada, they also embrace local conventions of liberal individualism that are typically at odds with their parents' gender norms. As they grow older and contemplate having children of their own, however, secondgeneration women talk of strengthening their links to the local African diaspora and extended networks in Africa. As the second generation ages and parents their own offspring, it remains to be seen whether there is more convergence among men and women, or whether these differences in gendered and racialized identities that are noticeable among adolescents and young adults, persist into mature adulthood.

\section{References}

Abdel-Shehid, G. 2005. Who Da Man? Black Masculinities and Sporting Cultures. Toronto: Canadian Scholars Press.

Arthur, J. 2000. Invisible Sojourners: African Immigrant Diaspora in the United States. Westport: Praeger.

Bourdieu, P. 1977. The economics of linguistic exchanges. Social Science Information, 16 (6): $645^{-}$ 668.

Brah, A. 1996. Cartographies of Diaspora: Contesting Identities. London: Routledge.

Brubaker, R. 2005. The 'diaspora' diaspora. Ethnic and Racial Studies, 28 (1): 1-19.

Chacko, E. 2003. Identity and assimilation among youth Ethiopian immigrants in Metropolitan Washington. Geographical Review, 93 (4): 491-506.

Clark, M. 2008. Identity among first and second generation African immigrants in the United States. African Identities, 6 (2): 169-181.

- 2009. Questions of identity among African immigrants in America. In: I. Okpewho and N. Nzegwu (eds.) The New African Diaspora. Bloomingston: Indiana University Press: 255-270.

Clifford, J. 1994. Diasporas. Cultural Anthropology, 9 (3): 302-338.

Collins, P. H. 2005. Black Sexual Politics: African Americans, Gender, and the New Racism. New York: Routledge.

Connell, R. W. 1995. Masculinities. Berkeley: University of California Press.

Creese, G. 2010. Erasing English language competency: African migrants in Vancouver, Canada. Journal of International Migration and Integration, 11 (3): 295-313.

Creese, G. 2011. The New African Diaspora in Vancouver: Migration, Exclusion and Belonging. Toronto: University of Toronto Press. 
Creese, G., E. N. Kambere and M. Masinda 2011. 'You have to stand up for yourself' African immigrant and refugee teens negotiate settlement in Vancouver. Metropolis British Columbia Working Paper Series, 11 (16).

Creese, G. and B. Wiebe 2012. 'Survival employment': Gender and deskilling among African immigrants in Canada. International Migration, 50 (5): 56-76.

Currie, D., D. Kelly and S. Pomerantz 2009. 'Girl Power': Girls Reinventing Girlhood. New York: Peter Lang.

Donato, K., D. Gabaccia, J. Holdaway, M. Manalansan and P. Pessar. 2006. A Glass Half Full? Gender in Migration Studies. International Migration Review, 40 (1): 3-26.

Emerson, R. 2002. 'WHERE MY GIRLS AT?' Negotiating Black womanhood in music videos. Gender and Society, 16 (1): 115-135.

Forman, M. 2001. 'Straight outta Mogadishu': Prescribed identities and performative practices among Somali youth in North American high schools. Topia 5: 33-60.

Frenette, M. and R. Morissette 2005. Will they ever converge? Earnings of immigrant and Canadian-born workers over the last two decades. International Migration Review, 39 (1): 228-258.

Fumanti, M. and P. Werbner 2010. The moral economy of the African diaspora: Citizenship, networking and permeable ethnicity. African Diaspora, 3: 3-12.

Galabuzi, G. E. 2006. Canada's Economic Apartheid: The Social Exclusion of Racialized Groups in the New Century. Toronto: Canadian Scholars' Press.

Gilroy, P. 1987. There Ain't no Black in the Union Jack: The Cultural Politics of Race and Nation. London: Hutchinson.

- 1993. The Black Atlantic: Modernity and Double Consciousness. London: Verso.

Goldring, L. 2001. The gender and geography of citizenship in Mexico-U.S. transnational spaces. Identities: Global Studies in Culture and Power, 7 (4): 501-537.

Gregoire, N. 2010. Identity politics, social movement and the state: 'Pan-African' associations and the making of an 'African community' in Belgium. African Diaspora, 3: 160-182.

Hall, S. 1990. Cultural Identity and Diaspora. In: J. Rutherford (ed.) Identity: Community, Culture, Difference. London: Lawrence and Wishart: 222-237.

- 2000. Old and New Identities, Old and New Ethnicities. In: L. Black and J. Solomos (eds.) Theories of Race and Racism: A Reader. London: Routledge: 144-153.

Handa, A. 2003. Of Silk Saris and Mini-Skirts: South Asian Girls Walk the Tightrope of Culture. Toronto: Women's Press.

Henry, F., C. Tator, W. Matttis and T. Rees 1995. The Colour of Democracy: Racism in Canadian Society. Toronto: Harcourt, Brace and Company Canada.

Ibrahim, A. E. K. 1999. Becoming Black: Rap and hip-hop, race, gender, identity, and the politics of esl learning. TESOL Quarterly, 33 (3): 349-369.

Ibrahim, A. 2003. Marking the unmarked: Hip-hop, the gaze and the African body in North America. Critical Arts: South-North Cultural and Media Studies, 17 (1-2): 52-70.

Jacobson, M. F. 1998. Whiteness of a Different Color: European Immigrants and the Alchemy of Race. Cambridge: Harvard University Press.

Jeffries, M. 2011. Thug life: Race, Gender and the Meaning of Hip-Hop. Chicago: University of Chicago Press.

Kelly, J. 1998. Under the Gaze: Learning to be Black in White Society. Halifax: Fernwood Publishing. - 2004. Borrowed Identities. New York: Peter Lang Publishing.

Kleist, N. 2010. Negotiating respectable masculinity: Gender and recognition in the Somali diaspora. African Diasporas, 3: 185-206. 
Koser, K. 2003. New African Diasporas: An Introduction. In: K. Koser (ed.) New African Diasporas. London: Routledge: 1-16.

Kusow, A. 2006. Migration and racial formations among Somali immigrants in North America. Journal of Ethnic and Migration Studies, 32 (3): 533-551.

Lewis, E. 1995. To turn as on a pivot: Writing African Americans into a history of overlapping diasporas. The American Historical Review, 100 (3): 765-787.

Manuh, T. 2003. 'Efie' or the Meanings of 'Home' among Female and Male Ghanaian Migrants in Toronto, Canada and Returned Migrants to Ghana. In: K. Koser (ed.) New African Diasporas. London: Routledge: 140-159.

Masinda, M. and E. N. Kambere 2008. Needs Assessment and Services Delivery Plan for African Immigrants and Refugees in Vancouver Metropolitan Area, British Columbia. Vancouver: United Way of the Lower Mainland and Umoja Operation Compassion Society.

Matsuoka, A. and J. Sorenson 2001. Ghosts and Shadows: Construction of Identity and Community in an African Diaspora. Toronto: University of Toronto Press.

Metro Vancouver. 2008. 2006 Census Bulletin: Data on Aboriginal Peoples. On-Line: http://www .metrovancouver.org/region/aboriginal/Pages/default.aspx (last visited 12th February 2013).

Mianda, G. 2004. Sisterhood versus discrimination: Being a Black African Francophone immigrant women in Montreal and Toronto. In: M. Epp, F. Iacovetta and F. Swyripa (eds.) Sisters or Strangers? Immigrant, Ethnic and Racialized Women in Canadian History. Toronto: University of Toronto Press: 266-284.

Morawska, E. 2011. 'Diaspora' diasporas' representations of their homelands: Exploring the polymorphs. Ethnic and Racial Studies, 34 (6): 1029-1048.

Ntarangwi, M. 2009. East African Hip Hop: Youth Culture and Globalization. Champaign: University of Illinois Press.

Okeke-Ihejirika, P. and D. Spitzer 2005. In search of identity: Intergenerational experiences of African youth in a Canadian context. In: W. Tettey and K. Puplampu (eds.) The African Diaspora in Canada: Negotiating identity and belonging. Calgary: University of Calgary Press: 205-224.

Pasura, D. 2008. Gendering the diaspora: Zimbabwean migrants in Britain. African Diaspora, 1 (1-2): 86-109.

Perullo, A. 2005. Hooligans and Heroes: Youth identity and Hip-Hop in Dar es Salaam, Tanzania. Africa Today, $5^{1}$ (4): 75-101.

Pessar, P. 2003. Engendering migration studies: The case of new immigrants in the United States. In: P. Hondagneu-Sotelo (ed.) Gender and US Immigration: Contemporary Trends. Berkeley: University of California Press: 20-42.

Picot, G. and A. Sweetman 2005. The deteriorating economic welfare of immigrants and possible causes: Update 2005. Statistics Canada Analytical Studies Branch Research Paper Series. Catalogue n. 11Foo19MIE, No. 262.

Plaza, D. 2006. The construction of a segmented hybrid identity among one-and-a-half-generation and second-generation Indo-Caribbean and African Caribbean Canadians. Identity: An International Journal of Theory and Research, 6 (3): 207-229.

Pratt, G. 2004. Working Feminism. Philadelphia: Temple University Press.

Puplampu, K. and W. Tettey 2005. Ethnicity and the identity of African-Canadians: A theoretical and political analysis. In: W. Tettey and K. Puplampu (eds.) The African Diaspora in Canada: Negotiating Identity and Belonging. Calgary: University of Calgary Press: 25-48.

Rose, T. 2008. The Hip Hop Wars. New York: Basic Books. 
Statistics Canada. Community Profiles, 2006 Census. On-Line: http://wwwi2.statcan.ca/censusrecensement/2006/dp-pd/prof/92-591/index.cfm?Lang=E (last visited 19th August 2012).

Statistics Canada. Special Interest Profiles, 2006 Census. On-Line: http://www12.statcan.ca/ census-recensement/2006/dp-pd/prof/92-591/details/page.cfm?Lang=E\&Geo1=CMA\&Code1= 933\&Geo2 $=$ PR\&Code2 $=59 \&$ Data $=$ Count\&SearchText=vancouver\&SearchType $=$ Begins\&Sear chPR $=01 \& B 1=A l l \& C u s t o m$ (last visited 16 th September 2012).

Statistics Canada 2007. Immigration in Canada: A Portrait of the Foreign-Born Population, 2006 Census. Catalogue no. 97-557-XIE.

Statistics Canada 2008. Canada's Ethnocultural Mosaic, 2006 Census. Catalogue no. 97-562-X.

Stephens, D. and A. Few 2007a. Hip hop honey or video ho: African American preadolescents' understanding of female sexual scripts in hip hop culture. Sexuality and Culture, 11 (3-4): 48-69.

Stephens, D. and A. Few 2007b. The effects of images of African American women in hip hop on early adolescents' attitudes toward physical attractiveness and interpersonal relationships. Sex Roles, 56: 251-264.

Vertovec, S. 1997. Three meanings of 'diaspora', exemplified among south Asian religions. Diaspora, 6 (3): 277-299.

Werbner, P. 2010. Many gateways to the gateway city: Elites, class and policy networking in the London African diaspora. African Diaspora, 3: 132-159.

Zeleza, P. T. 2005. Rewriting the African diaspora: Beyond the Black Atlantic. African Affairs, 104 (414): $35-68$. 